\title{
SMALL CLAIMS FOR ALBERTA: SOME RECOMMENDATIONS*
}

\author{
R. B. SPEVAKOW**
}

\begin{abstract}
Small claims courts have been the subject of legal and legislative scrutiny in a number of jurisdictions. This article examines the small claims system, paying particular attention to the underlying purpose of such a system: to provide the individual with an accessable means to obtain speedy, inexpensive and understandable redress. In light of this purpose, concerns that the courts may ignore the in. dividual (particularly when the individual is a defendant), and that the courts may be used as judicial collection agencies, are raised and discussed. Much attention is given to the format of the court and the roles of judge and lawyer. Although material is drawn from research done in several Canadian and American jurisdictions, discussion is aimed specifically at the situation in Alberta. Portions of the article are followed by recommendations aimed at remedying specific problems raised in the discussion.
\end{abstract}

\section{BACKGROUND}

As early as 1518, during the reign of Henry VIII in England, a statute was passed creating a Small Debts Court for the City of London. Blackstone describes this court as follows: 1

But there is one species of courts, ... which in its proceedings so varies from the course of the common law, that it may deserve a more particular consideration. I mean the Courts of request, or Courts of Conscience for the recovery of small debts . . . The constitution is this: two alderman, and four commoners, sit twice a week to hear all causes of debt not exceeding the value of 40 shillings; which they examine in a summary way, by the oath of the parties or other witnesses, and makes such order therein as is consonant to equity and good conscience. The time and expense of obtaining the summary redress are very inconsiderable, which make it a great benefit to trade.

The present county court system in England and Wales originated with a statute passed in 1846 . Its aim was to adapt the court ". . . to the needs of the great mass of the population by introducing the maximum of . . . simplicity of procedure; suitors being able in fact to obtain relief and defend themselves without legal assistance."2 However, as Leslie G. Kosmin, in an article entitled "The Small Claims Court Dilemma", notes, the principle of simplicity has not been adhered to: ${ }^{3}$

The County Court practice in England in 1969 contained 319 pages of rules, 204 of forms, over 2,000 pages of acts, tables of costs and fees as well as the statement 'legal representation is always desirable if obtainable'.

The handling of small claims in this court together with other court systems has been severely criticized by Terence G. Ison as being probably "... the most deplorable feature of the administration of civil justice".+

* Editor's note: On November 3, 1978, after the writing of this article, Bill 64 - The Provincial Court Act, 1978, was given Royal Assent. This Act has a bearing on Small Claims Court.

** Judge of the Provincial Court of Alberta.

1. 3 Blackstone, Commentaries on the Laws of England (1973) 81.

2. The County Court Practice (E. Dale 1969).

3. Kosmin, "The Small Claims Dilemma" (1976) 13 Huston L. Rev. 934 at 936.

4. Ison, "Small Claims" (1972) 35 Mod. L. Rev. 18. 
The first Parliament of Upper Canada in 1792 passed an Act with the declared objective of making available "an easy and speedy method of recovering small debts." 5 This Act provided for the establishment of a provincial court system known as Courts of Request. Two or more justices of the peace sat in each, having jurisdiction in debt to 40 shillings and to decree as to them should seem just in law and in equity.$^{6}$

Like their counterparts in England, the present small claims courts in Ontario have developed a structure having an Act with 198 sections, 70 rules of procedure, 86 forms, 25 supplementary forms and 6 pages on fees and costs.? The Ontario Act, however, is now the subject of substantial revision.

The history of small claims in the United States is summarized by Kosmin:8

In 1920, Massachussetts became the first state to create a state-wide system of small claims courts. California followed suit in $1921 \ldots$. . The activity reached its peak just before the Second World War, but from then until the rise of consumerism in the late sixties, very little attention was given to the small claims courts. They became, in the words of Judge Tim Murphy, 'the forgotten court'.9

The first milestone in Alberta for provincial small claims court was the passing of The Small Debts Act in 1918.10 This was an act respecting the recovery of small debts, with a monetary limit of $\$ 50.00$ in debt. Its jurisdiction was exercised by a justice of the peace or police magistrate. In 1924 the monetary limit was increased to $\$ 100.0011$ This limit stayed in effect until 1960 when it was increased to $\$ 200.0012$ It was amended again in 1963 to bring the monetary limit to $\$ 300.00 .13$ The inactivity between 1924 and 1960 was probably due to the small claims procedure in the Alberta District Court. It was, in effect, competitive with the Small Debts Court of that time.14 Small Claims Court was not forgotten but remained in the backwaters of the judicial system.

The next milestone in Alberta was in $1966^{15}$ when damage actions were introduced with a limit of $\$ 200.00$, and debt claims were increased from $\$ 300.00$ to $\$ 500.00$. In 196816 the title of the Act was

5. 32 Geo. 3, c. 6, as quoted in Kosmin, supra n. 3 at 936.

6. Kosmin, id.

7. See McKeon's Small Claims Court Handbook (3rd ed. Davies ed. 1975).

8. Supra n. 3 at 937.

9. Murphy, "D.C. Small Claims Court - The Forgotten Court" 34 J.B.A . of D.C. 14 (1967), as quoted in Kosmin, supra n. 3 at 937.

10. S.A. 1918 , c. 11 .

11. S.A. 1924 , c. 3 .

12. S.A. 1960 , c. 96 .

13. S.A. 1963 , c. 61 .

14. The District Court of Alberta has a small claims procedure established by the Rules of Court with a monetary limit of $\$ 500.00$. The procedure is not as complicated as the formal procedure in District Court. Litigants are allowed to represent themselves. In practice, however, representation is strongly suggested by the support staff and by some of the judges. Parties are not assisted in filing their claims. Public response to the use of this procedure, at least since the 1960's has been negative.

15. S.A. 1966, c. 94 .

16. S.A. 1968 , c. 93 . 
changed to The Small Claims Court Act. This Act contains substantially the same sections as does the present day Act. The latest legislation in Alberta was in 1976 when the Act was amended to increase the jurisdiction from $\$ 500.00$ to $\$ 1,000.00$ and from $\$ 200.00$ to $\$ 1,000.00$ in debt and damages respectively. ${ }^{17}$

Unlike the County Courts of England and the Small Claims Court of Ontario, the Alberta court has been changed primarily in connection with its monetary jurisdiction. It has remained informal and even now contains only 50 sections, a schedule of six forms and one page of fees.

Attention was focused on the small claims courts after the Second World War. This was due to the rise of consumerism, and the formation of consumer groups whose impact resulted in the passing of consumer protection legislation; greater public awareness of small claims courts; natural population increase; and the need for a forum, other than the existing formal court structure, to meet the needs of the great majority of the population.

\section{WHY A SMALL CLAIMS COURT SYSTEM?}

The need for a system other than the formal court system to deal with the needs of the great majority of the population was stressed by Roscoe Pound:18

It is here that the administration of justice touches immediately the greatest number of people. It is here that the great mass of an urban population. whose experience of the law in the past has been too often experience only of the arbitrary discretion of police officers, might be made to feel that the law is a living force for securing their individual as well as their collective interests. For there is a strong social interest in the moral and social life of the individual. If the will of the individual is subjected arbitrarily to the will of others because the means of protection are too cumbrous and expensive to be available for one of his means against an aggressive opponent who has the means or the inclination to resist, there is injury to society at large.

The importance of the small claims court system has been emphasized by many studies and articles. It was summed up in the Small Claims Courts briefing paper of January 1976, by the Ministry of the Attorney-General for the Province of Ontario, which stated:19

The small claims courts presently handle over $75 \%$ of civil actions and matters before Ontario courts. It is here that the appearance and the fact of justice is impressed first hand on the vast majority of citizens involved in a civil dispute. It is imperative that the presiding judiciary be of exceptional calibre.

\section{The Consumer Research Council of Canada states:20}

It is important to remember that small claims courts, together with traffic courts, are very often the only contact that citizens have with the judicial process and if they are given short shrift by the process, it has an important sociological impact on attitudes in the community in general.

The goals of small claims courts are ascertainable from the statutes creating them, the abundant literature written about them, and the conclusions and recommendations of empirical studies. Concisely put,

17. S.A. 1976, c. 58, changes effective January $1,1977$.

18. Pound, "The Administration of Justice in the Modern City" (1913) 26 Harv. L. Rev. 302.

19. Small Claims Court briefing paper, Ministry of the Attorney General, Ontario, 1976.

20. Sigurdson and Raine, Consumer Redress Mechanisms (Consumer Research Council, 1977) 49 . 
"the small claims court should be available and accessible to every person in order to provide simply, speedy, inexpensive and understandable justice."21

Optimism about and praise given to the small claims courts as late as 1955 is evidenced by the following:22

The original purpose of the small claims courts has been fulfilled. Many well-founded claims are presented which would never have seen the light of day because of the expense in bringing suit. A defendant also benefits. If he has a defence [sic], it will be heard and if he has to pay a just debt (and most individuals want to do just that) he is given an opportunity to pay it in instalments based on his ability.

This praise has given way to more critical and harsh opinions expressed by studies made of the small claims system in recent years. The findings of Robert Klein for Consumer Reports in the 1971 study of Small Claims Courts in Hartford, Connecticut; Hackinsaw, New Jersey; Detroit, Michigan and Berkeley, California, summarized the situation:23

\begin{abstract}
Small claims courts have been in large part a disappointment to those who thought they would serve the poor by creating a forum where costs were low, lawyers were unnecessary, procedures were simple, and justice was nevertheless disposed. The poor man who is a debtor is likely to stop paying when he discovers the merchandise is defective, the transaction is fraudulent, or the price is excessive. He then becomes the defendant in a case brought by the retailer or finance company. Then the small claims courts, like other civil courts, become a weapon against poor people. All the trappings intended to serve them will then victimize them instead. The speediness of the proceedings takes on the character of railroading. The informal procedures and pressures from the bench in some courts enable the company representatives to manoeuver consumers out of telling their story.
\end{abstract}

These findings in one form or another have generally been applied to the many small claims court systems established in England, the United States and Canada.

\title{
III. CONCERNS
}

\section{A. Ignoring the Individual}

One of the main criticisms of the small claims courts is that they have become judicial collection agencies. This label is a misnomer. Kosmin deals extensively with the small claims court system and areas where questions have been raised and improvements suggested. He states: ${ }^{24}$

The principal cause of the present weakness of the courts is probably that those who are least interested in seeing them function as the people's courts are those who use them most. Surveys have shown that the overwhelming majority of suits are brought by businesses and public utilities and that the defendants are usually private individuals . . In general, a default judgment rate of approximately $60 \%$ of those claims going to judgment has been observed ... Although some of these courts are indeed used as collection agencies, the same speedy and effective justice is available for consumer plaintiffs as well as for business plaintiffs. Statistics show that these courts would be more aptly described as plaintiffs' courts rather than as collection agencies, even though they presently are overwhelmingly used by creditor plaintiffs.

21. National Institute for Consumer Justice, Redress of Consumer Grievances (1973) 15.

22. Institute of Judicial Administration. Small Claims Courts in the United States (1955), as quoted in Kosmin, supra n. 3 at 939.

23. Klein, "Buyer vs. Seller in Small Claims Court" 36 Consumer Reports, Oct. 1971 at 624, as quoted in Kosmin, supra n. 3 at 939.

24. Kosmin, supra n. 3 at 940 [emphasis by writer]. 
The situation as described by Kosmin is relevant to the studies made in Alberta. J. W. Samuels found that finance companies, banks and big department stores represented $25.4 \%$ of the claims entered, while small businesses and individuals made up $69.8 \%$ of the total. 25

A study done at Osgoode Hall discovered that in small claims court actions involving consumers, the consumer most often plays the role of defendant. In $97 \%$ of the actions studied, the consumer appeared as defendant; in only $3 \%$ of the cases was a business party the defendant. The study concluded: 26

It seems, at least prima facie from this data, that the Small Claims Court may largely be functioning as a collection agency for business interests.

The reason businesses are using these courts more than individuals was best explained by Judge Skelly Wright as being 27

.. primarily because business concerns are aware of their rights and the poor are not. Consequently, the poor are usually the defendants, rather than the plaintiffs, in small claims courts. The poor lack the security and capacity to assert their rights, even when they recognize the rights. Indeed, most low-income consumers are unaware of the existence of the small claims court. They simply do not think in terms of invoking the legal process on their side. They have no confidence in the courts. Where the low-income consumer is irate enough to take action, he is likely to stop payment as a form of retaliation and thereby worsen his position.

In the quest to obtain a workable system to assist the individual before the court as a litigant, it has been assumed that the individual would be coming in as a plaintiff. The objective has been to make it more attractive to allow the plaintiff into court. It was not realized that the individual, more often than not, appears as defendant. The obvious defect, as stated earlier in this article, is that the trappings intended to serve the lay person as plaintiff will victimize him as defendant.

Alberta is not alone: the procedure is plaintiff-oriented. The plaintiff is given information and assistance from the staff if he desires it. $\mathrm{He}$ is advised as to procedure and is given assistance relating to the conduct of his case at the trial. When field studies are conducted and points are examined to make the system more workable, it is with the purpose of making the court system more available to the plaintiff, not to the lay person who appears as defendant.

Field studies have concluded that there is a huge business volume presently being dealt with in the small claims courts, which is mainly represented by corporation collection agencies, finance companies and the like. To bar them from appearing in small claims courts as has been done in some jurisdictions, notably Quebec, would effectively be to deny the lay person, for whom the court is intended, the right to raise his defences or counterclaims. Business firms and corporations should be entitled to appear in small claims courts but representation should not be in the hands of collection agencies as agents. Businesses,

25. Samuels, 'Small Claims Procedure in Alberta" (Research Project 4, Institute of Law Research and Reform of Alberta, 1969) 14.

26. Moldaver and Herliky, Consumer Litigation in the Small Claims Courts of Metropolitan Toronto: An Empirical Study (1976). See also, George W. Adams, "The Small Claims Court and the Adversary Process: More Problems of Function and Form" (1973) 51 Can. Bar Rev. 583.

27. Wright, The Courts Have Failed the Poor, N.Y. Times, March 9, 1969 as quoted in Kosmin, supra n. 3 at 942. 
both large and small, should be filing their own claims through their own employees as officers as agents and not through commercial agencies.

\section{RECOMMENDATIONS}

1. A procedure should be instituted whereby defences, counterclaims, or admissions may be filed prior to the actual trial date.

2. As much information should be provided to defendants on admissions, trial procedure, and filing defences and counter-claims, as is now given to plaintiffs.

3. A limit should be fixed of 60 days from filing to trial. (This seems to be the consensus in order to comply with the objective of speedy determination. ${ }^{28}$ )

4. Collection or other commercial agencies should be barred from filing claims as agents for business or individuals.

The last recommendation may seem harsh but is supported by Barnett, Prov. Ct. J. in the British Columbia decision of Valley Credits Ltd. v. Key. ${ }^{29}$ The learned Judge stated:

In conducting its action in court the present plaintiff [collection agency] has displayed, at times, a marked lack of understanding of fundamental principles. Thus, in one case it sued in its own name (although it did not hold an assignment) upon the claim of a creditor who had specifically denied the plaintiff authority to commence court action on his behalf; in another case it issued a garnishing order on behalf of a judgment creditor and claimed the full amount of the judgment debt although the judgment debt had been previously paid; in another case it commenced an action as the assignee of the Insurance Corporation of British Columbia alleging a claim for damages arising out of a motor vehicle accident. The very same cause of action had previously been tried and judgment in a lesser amount than was claimed had been given in favour of I.C.B.C.'s insured party; and in still another case it sued as the assignee of the Town of Williams Lake claiming $\$ 10.00$, allegedly a debt owing for services rendered. In reality, the claim was for parking meter fines.

A similar situation arose in Alberta when a property management firm sued for rent on behalf of its principal in the Edmonton Small Claims Court. The defendant tenant tried to pay the rent prior to the date of the hearing and was advised that the amount owing was increased by $\$ 20.00$ for legal costs charged by the property management firms. As stated by Barnett, Prov. Ct. J., these examples are representative, not exhaustive. Most of the American authorities hold that, by bringing action either as assignee or in the name of the client, the collection agencies are practising law. After listing the injustices perpetrated by the collection agency, plaintiff in Valley Credit Ltd., Barnett Prov. Ct. J. stated:

They [that is, the examples given] demonstrate the wisdom of the American decisions which I have quoted.

Collection agencies cannot conduct proceedings as assignees or on behalf of clients in Alberta.30 However, they can file claims as agents. It is this practice which must be curtailed.

B. Default Judgments

The matter of default judgments has caused concern in that there

28. See Kosmin, supra n. 3 at 954 .

29. [1977] 2 W.W.R. 422 at 437.

30. See The Legal Professions Act, R.S.a. 1970, c. 203, s. 92. 
seems to be a movement to make default judgments as readily available as they are in District Court.31 Lawyers argue that if they are able to obtain a default judgment "over the counter" in District Court for thousands of dollars, they should be able to do the same in Small Claims Court for hundreds of dollars, rather than prove their claim.

It has been argued that the same procedures available to lawyers should be available to the individual in small claims courts.32 Kosmin states the problem:33

The volume of default judgments issued by the small claims courts is a matter of considerable concern. As mentioned earlier, a default judgment rate of approximately $60 \%$ has been ob. served but higher rates are quite common.

\section{Kosmin refers to Klein's study which noted:34}

Many small claims courts grind out default judgments against consumers for unpaid debts without even questioning whether these debts were based on legal and equitable instalment terms, whether the consumer may have been pressured into signing a contract by fraudulent sales tactics, or whether the consumer was refusing to pay for shoddy goods.

The report of an American Small Claims Study Group recommends that in order to redress the present imbalance in the court procedure favouring the business plaintiff 35

... judges and arbitrators should be required to examine critically all business claims in accordance with the principle of caveat venditor, without regard to whether or not the defendant has defaulted.

The procedure which has the support of the local Bar Association in New York puts the judge or arbitrator in the role of a devil's advocate. He must inquire into what efforts were made by the plaintiff to collect through informal means, and generally no default judgment issues in favour of a plaintiff who did not try to establish some sort of contact with the defendant. A bill presented by Senator Magnussen which was before the United States Senate had, as one of its provisions, that a small claims court would be regarded as responsive to national goals if it 36

... discourages the entry of judgements by default by requiring, as a prerequisite thereto that the appropriate judge find, after a proceeding in open court, that -

(A) the defendant was given adequate notice of such claim;

(B) the defendant understood the nature of the claim and proceedings:

(C) the plaintiff established a prima facie case demonstrating entitlement to judgment.

Kosmin suggests that the volume of default judgments could be reduced by sending along with the summons a short leaflet, in plain language, explaining to the defendant what he must do, and giving him the address and telephone numbers of the court or the community advocate's office and the nearest legal advice centre, so that he may contact them for assistance.

31. This suggestion has come from lawyers, newly-appointed judges and the Omega Report, infra n. 32.

32. S. Corke, Project Omega, Small Claims Report (1978).

33. Kosmin, supra n. 3 at 967.

34. Id.

35. Small Claims Study Group, Little Injustices: Small Claims Courts and the American Consumer (Weiss ed. 1972) 22.

36. S. 2928, 93d Cong., 2d Sess. 8, 7 (c) (6) (1974), as quoted in Kosmin, supra n. 3 at 969. 


\section{RECOMMENDATIONS}

5. Default judgments should not be made easier in Alberta. They should require that, after a proceeding in open court, the judge find that the defendant was served with the claim, and that the plaintiff has established a prima facie case demonstrating entitlement to judgment.

6. Defences normally required to be raised in the pleadings should not be necessary in the small claims court; that is, the statute of limitations and the like need not be pleaded in order to raise them as defences.

7. Leaflets should go out with the dispute note and counter-claim explaining to the defendant the steps he must take and giving him telephone numbers and addresses where legal assistance can be obtained. (See Recommendation 2.)

\section{THE DILEMMA:}

\section{LEGAL FORMALITIES AND SMALL CLAIMS PROCEDURE}

People trained in the law, including judges who preside in the small claims courts, are well aware of the various devices such as detailed pleadings, discoveries, rules of evidence, formal service of documents, and other procedural rules that have been established over the years in a formal court system. These are all designed to ensure the accuracy, reliability and legitimacy of a claim. These procedural devices, together with such substantive rights as the defendant's right to know the plaintiff's case, and both parties' right of representation, give rise to a conflict among legally trained people when they are dealing with a small claims system with its objective of speed, economy, informality and accessibility. There arises the very real dilemma between the adversary system with its principle of representation, and the informality of small claims procedure where lawyers may not be required.

The objective of speedy determination in the small claims system conflicts with the requirement of time consuming pleadings and discoveries in the formal system. For example, how is a judge to apply the rules of evidence in an action such as one involving damages to a motor vehicle, in light of the decision of Cormack J. of the District Court of Alberta in the case of Schwartz v. Dickie? 3 ; The facts were as follows: the only proof of damages submitted was for estimates: one in the amount of $\$ 100.90$ and a second in the amount of $\$ 49.38$. Neither estimator was called as a witness. It was held by the learned judge that the plaintiff failed to prove his damage sufficiently to enable the court to fix damages within the required definitions. Are such formal evidentiary requirements to be disregarded in small claims courts because the cost factor in bringing the mechanics as witnesses may be too high? Or, are we to apply them in all cases? What evidence is a small claims court judge to accept in cases of general damages for injuries where doctors' opinions are not only required but the doctors 
themselves are asked to appear? These questions are especially important now that the monetary limit on damages is $\$ 1,000.00$ instead of $\$ 200.00$.

With the increase in monetary jurisdiction, especially in damage actions, the type of case handled in small claims courts will change. It is likely there will be many cases involving complex issues of liability and quantum in damage claims (both general and special) for personal injuries. The nature of evidence required will affect the character of the system. Inexpensive, informal proceedings would conflict with established rules and procedure which ensure the legitimacy, reliability and accuracy of a claim. It is felt that a monetary limit is reached when well-established rules, devices, and principles of law cannot give way to speed, informality and low cost. It is in this area that the writer feels a great deal of concern because various reports have recommended a substantial increase in jurisdiction in the small claims area. Yet, the report prepared by Consumer Affairs ${ }^{38}$ indicates that the average claim throughout Canada was well below the limits established in the jurisdictions in which claims were filed.

In view of recent proposals to provide a civil jurisdiction for provincial courts it is felt that such increased jurisdiction could not be placed in the small claims court without destroying its unique function of providing informal, speedy and inexpensive justice. It is felt that any increase in monetary jurisdiction would tip the scales towards the more formal court structure with its devices and principles that have been established in the common law system to get at the accuracy, truth and legitimacy of a claim. If further increases are contemplated, then a more formal court structure should be devised to receive them. It is felt that the simplest procedure would be to adopt the District Court Act of $1971^{39}$ (in which the monetary jurisdiction was $\$ 2,000.00$ ) and name it the Provincial Court Act, taking out such sections as would contravene The British North America Act40 as unconstitutional, and adopting such Rules of the Supreme Court of Alberta as are necessary to make the court function. The new Act should also include the provision that the judges appointed to preside in these courts would, as part of their duties, handle small claims under a small Claims Act.

It is not felt that the Province of Alberta has need of a provincial court of civil jurisdiction, other than the Small Claims Court, as long as both the District and Supreme Courts operate in an original jurisdiction in the same area. The complications of establishing further courts of concurrent jurisdiction with the District Court, without infringing on The British North America Act, would render such a provincial court meaningless. A merger of the District and Supreme Courts might pave the way for establishing a meaningful provincial court of civil jurisdiction.

To recapitulate: If the present District Court merges with the

38. "Small Claims Procedures Across Canada" Consumer Research Report $=8$ (1974); see also Sigurdson and Raine, supra n. 20.

39. R.S.A. 1970, c. 111.

40. See R.S.C. 1970, Appendix II. 
Supreme Court then the present Small Claims Court must be expanded, but its present character must be maintained.

To achieve this, the only viable method, in the writer's opinion, is to have two levels of jurisdiction: a small claims procedure and format, and a large claims procedure with a slightly more sophisticated format. This two-tiered system seems, at first blush, to mirror the present situation in District Court. However, in closer analysis, it is readily apparent that the crucial requirements of speed, informality and accessibility of the small claims system would remain intact. Any other solution would probably create another District Court with a provincial name.

It must be stressed that any increase in monetary jurisdiction in the small claims court would only alter its character in such a manner that its goals would have to be re-examined in the light of established principles. It is for these reasons that the writer feels close scrutiny should be made of the monetary limits in the small claims courts and those limits should not be increased without a careful examination of the effect of such an increase on the system.

\section{RECOMMENDATIONS}

8. The monetary limit of $\$ 1,000.00$ should not be increased in small claims simply to provide a provincial civil jurisdiction concurrent with Alberta's District Court but should be considered in the light of the economy (i.e. inflation).

9. Claims for general damages for personal injuries should be excluded.

10. Appeals should be limited to matters of law only.

11. A reasonable flexibility in the hearing should be allowed with respect to rules of evidence. A total adherence to such rules would encumber the objectives of small claims.

\section{THE FORMAT OF THE COURT \\ AND THE ROLES OF JUDGE AND LAWYER}

A. Format of the Court

Much discussion has centered around the format that the small claims courts should establish with respect to trials and, in particular, the roles of judges and lawyers in a small claims court. Terence G. Ison takes a radical view: 41

The trouble with the small claims courts is that although they use a procedure that is simpler
than in the higher courts, they still operate on basically the same principles. The small
claims judge tends to imitate his superiors in the adversary system. If justice is ever to be
done in small claims, the approach must be far more iconoclastic. Indeed, almost every prin-
ciple that a common lawyer has cherished must be abandoned. The adversary system, the rules
of evidence, the dignity of the courtroom, the concept of the trial; all must go... Above all,
the judge's function must be recognized as first and foremost the task of investigation, with
adjudication being an ancillary role.

He advocates further that there should be no requirement that a claim be in writing, that default judgments should be abolished, and that the judge should go out "on call" and give judgments on the spot. 
In connection with this topic, George W. Adams' article The Small Claims Court and the Adversary Process: More Problems of Function and Form:2 is well worth exploring. The author sets out the two main legal processes, namely, the adversary process which is found in most common law jurisdictions and the inquisitorial process which is found in most civil jurisdictions.

Adams defines the adversary process: 13

Adjudication by way of an adversary process is where, as prelude to the dispute being solved by the application of law, the interested parties have the opportunity of adducing evidence (or proof) and making arguments to a disinterested and impartial arbiter who decides the case on the basis of this evidence and the arguments.

He perceives a number of advantageous features to this system. Litigants are involved in preparation and argument of their cases, and such involvement makes it more likely that the result will be acceptable to the parties. The arbiter is not involved in research and presentation of the case and thus is more able to be and to appear to be impartial. There is a cost saving to society because the parties bear responsibility for preparing and bringing their cases to court. Furthermore, the percentage of cases settled under the adversary process is high as the process tends to encourage negotiation, and to view the courts as a last resort.

By contrast, adjudication by way of inquisition ${ }^{44}$

... requires an expert decision-maker to actively investigate the claims of unrepresented litigants and then to subject his findings to the relevant law without assistance from the affected parties. To contrast this procedure with the adversary process, it might be said that the decision maker plays three roles in the course of his determination: the judge, the plaintiff and the defendant. This procedural model would appear to draw its sustenance from the concept of scientific enquiry.

Adams outlines a number of defects in the inquisitorial system. The ideal of impartiality is undermined: the decision maker must start with a working theory in order to investigate the facts. The parties are not involved in conducting the case, which can create the appearance of arbitrariness and may raise a suspicion of bias. Negotiated settlements are virtually eliminated: unrepresented parties must depend upon the expert decision maker to make the determination of the case. The time and costs involved in investigating all cases undermine the aims of speed and economy which are so important to a small claims system. Because both sides of the issue are effectively presented by the same person, creativity of adjudication is limited. Finally, it is difficult for the decision maker to fulfil the role of conciliator: any confidential information given to a conciliator who is also the decision maker may prejudice the positions of the parties if the conciliation fails and adjudication becomes necessary. Adams concludes that, in theory at least, the adversary system is the better one.

Adams points out that the main disadvantage of the adversary process is that it has created two legal systems: one for people who are able to afford or merit the services of a lawyer and another for

42. Adams, supra n. 26.

43. Id at 593 .

44. Id. 596. 
those people who cannot. The great majority of disputes are adjudicated by this latter system where one or both of the litigants may be unrepresented. This system produces "... 'mass' decision making that, as a consequence, is either uninformed if the judge remains passive, or potentially biased if the judge assumes an inquisitorial posture." 45

Law makers as well as other pressure groups have encouraged the development of the inquisitorial role of judges in small claims courts by the legislation and directions given to such courts. Unfortunately small claims courts have moved away from the adversary system of adjudication in the attempt to make the choice ". . . between the Scylla of bias through inexpensive inquisition and the Charybdis of costly due process through adversary proceedings . . "..46

Adams quotes from Roscoe Pound's comments respecting the conduct of petty litigation: ${ }^{47}$

In petty cases there ought to be no expensive advocacy. One side or the other, unless the game of litigation is played for pure pleasure, cannot afford it. The court, therefore, has no assistance, or no adequate assistance. Hence the judge cannot be a mere umpire. He must actively seek the truth and the law, largely if not wholly unaided. The lay vision of every man his own lawyer has been shown by all experience to be an illusion. The other extreme, a professional lawyer for every man, has no place in petty litigation. The alternative is a judge who represents both parties and the law, and a procedure which will permit him to do so effectively. No doubt he should have assistance in the way of clerks, who may save valuable judicial time by showing parties how to present their respective claims. At any rate our first concern in a people's court is a procedure that will help parties assert and secure their rights, and to get away from the involved and over-mechanical procedure which has become in so many jurisdictions a means afforded each party of hindering the other in his search for justice.

\section{Adams concludes: 18}

Small claims court legislation, therefore, implicitly sanctions an inquisitorial procedure and it is important to observe that this procedure is conducted on an "assembly-line" basis . . . The cost of providing a more adversary hearing, or of employing more inquisitors, for that matter, may have been deemed excessive: 'Petty justice for petty claims' being the major unarticulated premise. Unfortunately, the individuals affected by this intuition have little political power to contest the premise's validity ... "Assembly-line" inquisitions, while speedy and cheap, smack of arbitrary hypocrisies so familiar to the "masses": and this may be only one reason for despair. An inquisition is preferable to leaving unrepresented individuals at ther mercy of institutional litigants, and this procedural choice is left in the hands of individual judges. Small claims court legislation does not require an inquisitorial judicial posture and recent empirical evidence highlights the great potential for procedural abuse should a judge decide to remain passive.

It is felt that the adversary system in theory is best for small claims in a common law jurisdiction; and that, in addition to other defects, a different system may cause resentment and a feeling of discrimination on the basis of affordability. It is suggested that precautions be taken to avoid legislation that creates an inquisitorial format.

\section{$B$. The Judge and the Lawyer}

Adams feels that the appointment of judges in small claims should be carefully considered. He notes that many judges find the work

45. Id. at $602-603$.

46. Id. at 606 .

47. Pound, supra n. 18, as cited in Adams, id. al 607.

48. Adams, id. at 608. 
unrewarding and may tend to downgrade its importance or try to disengage themselves from this type of work. To deal with this, he recommends an attempt to increase interest and concern: appointments to small claims court should be full time; intellectual interchange and communication should be encouraged and facilitated.49

\section{Kosmin agrees with most of Adams' observations:50}

The role of the judge in a small claims court is an extremely difficult one. He is typically drawn from the regular civil court bench and will have been trained in the traditional common law adversarial trial process, yet his task in the small claims court is to assume an inquisitional role. He cannot afford to be a passive umpire, but must actively participate in the proceedings by cross-examining the parties and their witnesses to discover all the facts of the case. In many cases he is unassisted in this task, owing to the absence of lawyers for either party. Unfortunately, his position has frequently been considered as one of little importance. and many judges dislike sitting in the small claims court. They regard the work as tiresome, if not odious. Occasionally .... this results in their giving vent to frustrated vaudevillian impulses when holding small claims court.

The report of the American Small Claims Study Group ${ }^{51}$ concluded that those judges who do not wish to serve in small claims court should not be required to do so. The report advocated an annual conference of small claims judges and a continuing program of in-service education dealing with new developments in consumer law, conciliation techniques and innovations in small claims procedure. It has also been suggested that judges from the regular court system sit in small claims on a rotational basis as it is believed that this practice enhances the court's image.

The above recommendations were supported by the National Institute for Consumer Justice52 which further asserted that the rotation of regular civil court judge will maintain the status of the courts more effectively than the permanent assignment of an individual judge. Kosmin concludes that those who do not wish to serve should be excused $^{53}$

as patience and enthusiasm are essential requirements for the job. Such a practice will enhance the status of the court, will enable the judiciary to familiarize themselves with the legal problems that arise at this level and will thus aid the progressive development of the law.

It appears from the material examined that the role of lawyers, although not excluded, would be limited. Their presence has provided some safeguard from the dispensing of "palm tree justice". One study, considering whether lawyers were necessary in small claims court, concluded that unless paralegal services were provided to potential litigants, lawyers were helpful in "sifting out" cases with no legal base, and preparing for trial.54

The consensus of writers seems to be that lawyers should be barred from appearing; but the writer feels that lawyers can be helpful to

49. Id. at 612 .

50. Kosmin, supra n. 3 at 954 [emphasis by writer].

51. Supra n. 35 at 25.

52. Supra n. 21 at 20.

53. Kosmin, supra n. 3 at 957.

54. Weller, Ruhnka and Martin, "Success in Small Claims: Is a Lawyer Necessary?" (1977) 61 Judicature 176. 
the litigants, the court and the system, although their role in the court should be to assist the client to carry his case rather than to carry it for him. The role might be considered to be more that of an amicus curiae than that of an advocate.

\section{RECOMMENDATIONS}

12. The adversary system should be considered as best in theory but judges must adopt an active role and safeguard against administering "palm tree justice".

13. Selection of judges to preside in small claims should be carefully considered and those who do not wish to serve should be excused.

14. Judges should be rotated from amongst the regular judges to enhance the court's image as being part of the judicial system.

15. A judges' program should be established to include conferences, seminars and meetings relating to: preparing a judges' handbook; continuing education with respect to developments in consumer law; training in conciliation techniques; and consideration of innovations in small claims procedure.

16. The Assistant Chief Judge should be made responsible for coordinating the activities of judges and establishing continuity and consistency of small claims procedure. This is especially important when considering: rotation of judges who are willing to sit in small claims court; data processing and planning for immediate and future needs to correct or prevent deficiencies in the system, and a community lay advocate program.

17. Lawyers should be allowed to appear but their participation limited through nominal fees. Lawyers should participate primarily as assistants, of the client and the court, rather than as advocates.

18. Judges should be given power to limit roles of lawyers.

19. Judges should be empowered to fine for contempt as in other courts and other small claims systems, and to issue warrants when subpoenas are disobeyed.

20. Judges should be empowered to grant both monetary and equitable relief which would be limited to orders to repair, replace, refund, reform and rescind.

21. Court should be of record.

It is the writer's opinion that, in Alberta at least, the adversary system should be retained and that lawyers should be allowed to represent the parties but that their role should be limited. The judge in such a system must not remain passive but must be able to ask questions and cross-examine witnesses and the parties, as well as suggest procedure to be followed. The judge should be aware of procedural devices as well as the rules of evidence but should not apply them rigidly and perhaps this should be made explicit in any legislation dealing with small claims. 


\section{RECENT DEVELOPMENTS}

To deal with the heavy volume of cases going through small claims courts and to provide more involvement by lay people, some jurisdictions have adopted a conciliation or mediation format as part of the small claims system.

These courts, as they are loosely called, are formed under the auspices of the administrative judge in small claims with committees comprised of lay people and lawyers. Their function is to sit at convenient hours (usually evening) in neighbourhood recreation and community centres staffed by lawyers, articled students, law students and some clerical assistants. The provide advice to actual or potential litigants; mediate the dispute if the parties so agree; arbitrate the dispute, with the agreement of the parties, if mediation fails; refer the parties to small claims court if arbitration is refused.

The settlements or arbitration awards must be approved by the administrative judge and there is no appeal from an arbitration award. This process loosely describes the practice in various jurisdictions incorporating conciliation.

The City of New York has a procedure whereby litigants may consent to arbitration before a referee or arbitrator who is usually a senior clerk or member of the bar. His decision if final; from it there is no appeal. The arbitrators are appointed by the administrative judge from a list of names submitted by the New York State or New York City Bar Association and indications are that the list is very active. They are available in court and the litigants appearing can go immediately into arbitration if agreeable.

The City of San Jose in California has set up what it calls "Neighbourhood Small Claims Courts".55 A Citizens Advisory Committee was established to provide assistance in developing plans and implementing and running the project under the auspices of the administrative judge in small claims. The experiment has been running without cost to the taxpayer as the services are voluntary. The system uses volunteer lawyers, mediators and arbitrators. The facilities are usually recreation or community centres, and meetings are held during the evening. The sessions are really pre-trial hearings. They serve to prevent frivolous claims or defences, and to eliminate claims or defences not founded in law; as well, advice is given to prepare parties for trial. The experiment also provides for mediation to try to arrive at a settlement. If mediation is not accepted, arbitration is suggested which, if consented to, takes place before another person to avoid the "without prejudice" conciliation from affecting the arbitration. If one or both parties object to arbitration the matter is set over for trial to the small claims court during the day.

A similar experiment has been conducted in British Columbia and a 1976 report by the Justice Development Commission indicated the success of the project: "The use of mediation as an integrated part of the court process was successfully demonstrated to the satisfaction

55. Bereford and Cooper. "A Neighbourhood Court for Neighbourhood Suits" (1977) 61 Judicature 185. 
of the public and judiciary." 56 The project provided a small claims legal advice clinic which operated on a daily basis. A weekly clinic was created on a permanent basis as part of the law students' legal advice program.

Ontario has incorporated similar features in a referee system.

\section{RECO'MMENDATIONS:}

22. It is recommended that a community law advoate program be considered in drafting a new Act. There should also be provision for such a program as ancillary to the present Small Claims Courts. It should be organized in committees under the Assistant Chief Judge and should include lay people, lawyers and law students. its staff, except for clerical staff, should be voluntary, and could include people from Consumer Affairs and the Landlord and Tenant Advisory Board. Its program should be to establish meeting places at convenient hours in neighbourhood localities for the purposes of giving advice, providing mediation, providing arbitration and publicizing not only the program but also the small claims forum to the public.

Kosmin states that such a scheme could "revolutionize the role of the courts and help restore them to their original purpose which is to provide a means of redress for the ordinary citizen." 57

\section{CONCLUSION}

Apropos the Alberta situation, a pertinent comment can be quoted from an article entitled Devising Procedures that are Civil to Promote Justice that is Civilized: ${ }^{58}$

We shall be self-defeatingly quixotic if we try to devise a system of Rolls Royce judicial treatment to deliver perfect justice in each of millions upon millions of cases. We need the highest quality we can possibly achieve in our system, our procedure, our management methods and personnel, and in the judges who preside in our courts.

Small claims courts in Alberta have operated as individual courts in various districts. There have been no pivotal points created to co-ordinate the various small claims courts into a unified or standard provincial court system. Hence, we have different policies in different areas established by different judges. Clerks have been given very little direction and no status. If problems arise in a district, a clerk or judge passing through might try to cope, perhaps creating a procedure which is repeated for better or worse. Edmonton and Calgary, because of volume, have been regarded as the authorities on which other districts may or may not rely. The procedure in these cities differs. Suggestions for reform have been piecemeal and patchwork without regard to establishing an overall policy, a system, or exchanges of information, recomendations and ideas.

It is suggested that recommendations of the Omega Report relating to administration are applicable and should be considered very carefully. If some of those recommendations have found their way into this paper then it reinforces the writer's adoption of them.

56. B.C. Justice Developemnt Commission, Small Claims Project (1976).

57. Kosmin, supra n. 3 at 964.

58. Rosenbeg. "Devising Procedures That are Civil to Promote Justice That is Civilized" 69 Mich. L. Rev. 797 at 912.813. 


\section{RECOMMENDATIONS}

23. Committees of judges and clerks should be established to create handbooks for judges and clerks, to arrange seminars and conferences, and to establish a standard data process to elicit problems and assist in day to day management and future planning under the aegis of the Assistant Chief Judge.

24. A committee should be established to consider revising the Small Claims Act.

25. A committee should be established to develop certain rules of procedure. That could perhaps be incorporated in a judges' handbook.

26. Committees established under recommendations (24) and (25) should consider the following:

(a) whether service of a summons could be by double registered mail or personally by a person other than the plaintiff.

(b) whether service of other documents, e.g. Defence, etc., could be by certified mail.

(c) whether the summons could be signed by the clerk, not the judge.

(d) whether service exjuris could be dispensed with as a requirement for out of province defendants.

(e) whether Rule 66212) of the Rules of Court (Small Claims Procedure) could be used rather than orders for substitutional service:

Rule 662(2) Every summons shall be served in the same manner as service of a Statement of Claim may be made; but the Court may, notwithstanding the fact that the Summons has not been served in the required manner, if it is satisfied that the Summons and dispute note have come to the attention of the Defendant, deem the defective service to have been good and valid service on the Defendant.

(f) whether Rule 551(1) should be incorporated:

Rule 5.5111/ An attendance on a motion in chambers or on an appointment before a master or other officer for half an hour next immediately following the time of the return thereof shall, in the absence of the opposite party, be deemed a sufficient attendance.

The writer feels that small claims in Alberta has come a long way from its beginnings in providing a forum for the lay person to process his legal difficulties. It is to be hoped that we will keep up this progress and perhaps lead in creating the highest quality in our system, our procedure, our management methods and personnel and in the judges who preside in our courts. Perhaps then, for individuals involved in the small claims system, Voltaire's classic statement will lose some of its sting: 59

Only twice in my life have I felt utterly ruined: once when I lost a lawsuit and once when I won.

59. As quoted in Kosmin, supra n. 3 at 935. 